\title{
The geomorphological effect of cornice fall avalanches in the Longyeardalen valley, Svalbard
}

\author{
M. Eckerstorfer ${ }^{1,2}$, H. H. Christiansen ${ }^{1}$, L. Rubensdotter ${ }^{3}$, and S. Vogel ${ }^{1}$ \\ ${ }^{1}$ Arctic Geology Department, University Centre in Svalbard, P.O. Box 156, 9171 Longyearbyen, Norway \\ ${ }^{2}$ Earth Observation, Norut, P.O. Box 6434, Troms $\varnothing$ Science Park, 9294 Troms $\varnothing$, Norway \\ ${ }^{3}$ Geological Survey of Norway, P.O. Box 6315, Sluppen, 7491 Trondheim, Norway \\ Correspondence to: M. Eckerstorfer (markus.eckerstorfer@norut.no)
}

Received: 4 November 2012 - Published in The Cryosphere Discuss.: 4 December 2012

Revised: 28 June 2013 - Accepted: 2 August 2013 - Published: 5 September 2013

\begin{abstract}
The study of snow avalanches and their geomorphological effect in the periglacial parts of the cryosphere is important for enhanced geomorphological process understanding as well as hazard-related studies. Only a few field studies, and particularly few in the High Arctic, have quantified avalanche sedimentation. Snow avalanches are traditionally ranked behind rockfall in terms of their significance for mass-wasting processes of rockslopes. Cornice fall avalanches are at present the most dominant snow avalanche type at two slope systems, called Nybyen and Larsbreen, in the valley Longyeardalen in central Svalbard. Both slope systems are on northwest-facing lee slopes underneath a large summit plateau, with annual cornices forming on the top. High-frequency and magnitude cornice fall avalanching is observed by daily automatic time-lapse photography. In addition, rock debris sedimentation by cornice fall avalanches was measured directly in permanent sediment traps or by snow inventories. The results from a maximum of seven years of measurements in a total of 13 catchments show maximum mean rock debris sedimentation rates ranging from 8.2 to $38.7 \mathrm{~kg} \mathrm{~m}^{-2}$ at Nybyen, and from 0.8 to $55.4 \mathrm{~kg} \mathrm{~m}^{-2}$ at Larsbreen. Correspondingly, avalanche fan surfaces accreted from 2.6 to $8.8 \mathrm{~mm} \mathrm{yr}^{-1}$ at Nybyen, and from 0.2 to $13.9 \mathrm{~mm} \mathrm{yr}^{-1}$ at Larsbreen. This comparably efficient rockslope mass wasting is due to collapsing cornices producing cornice fall avalanches containing large amounts of rock debris throughout the entire winter. The rock debris of different origin stems from the plateau crests, the adjacent free rock face and the transport pathway, accumulating distinct avalanche fans at both slope systems. Cornice fall avalanche sedimentation also contributed to the development
\end{abstract}

of a rock glacier at the Larsbreen site during the Holocene. We have recorded present maximum rockwall retreat rates of $0.9 \mathrm{~mm} \mathrm{yr}^{-1}$ at Nybyen, but as much as $6.7 \mathrm{~mm} \mathrm{yr}^{-1}$ at Larsbreen, while average Holocene rockwall retreat rates of $1.1 \mathrm{~mm} \mathrm{yr}^{-1}$ at Nybyen have been determined earlier. As cornice fall avalanches are the dominant type of avalanche in central Svalbard, the related geomorphological effect is assumed to be of significance at periglacial landscape scale. A climate-induced shift in prevailing winter wind direction could change the rockslope sedimentation effectively by changing the snow avalanche activity.

\section{Introduction}

In the periglacial parts of the cryosphere, snow and thus avalanches can be of geomorphological significance. The role of snow avalanches (hereafter called avalanches) as sediment erosion, transportation and accumulation agents is often underrated (Sass et al., 2010). Their geomorphological importance depends on the slope relief, the lithology and the climate favorable for avalanche release (French, 2007; Caine, 1976; Decaulne and Saemundsson, 2006; Luckman, 1977), as well as the supply of water/snow. Avalanche-derived landforms, created under periglacial or paraglacial conditions, are usually seen as rather short-lived landforms, whose activity stops once the climate becomes less favorable or the water/snow source disappears (André, 2003; Ballantyne and Benn, 1994).

Avalanche sedimentation rates are the quantification of rock debris transported and deposited by avalanches on 
avalanche fans, and are thus the most direct measure of the geomorphological effect of avalanches (Blikra and Selvik, 1998; Christiansen et al., 2007). Rockwall retreat rates quantify the potential geomorphological effect of avalanches on backwards erosion of a rockslope (Krautblatter and Dikau, 2007). Such quantification is done either by indirect methods using talus slopes as an inventory of long-term deposition (Schrott et al., 2002), or by direct measurements quantifying debris deposition (Luckman, 1978b). Both approaches were pioneered by Rapp in the 1950s (Rapp, 1960a, b).

Studies focusing solely on avalanche sedimentation are sparse. With a length of $13 \mathrm{yr}$, the longest record of avalanche sediment transport and accumulation quantified through direct measurements comes from the Canadian Rocky Mountains (Luckman, 1978a, 1988). Debris accumulation by avalanches was maximum $5 \mathrm{~mm} \mathrm{yr}^{-1}$ during the $13 \mathrm{yr}$ period; however, rockfall was the dominant debris transport agent. Rapp (1960b) quantified avalanche sedimentation in Kärkevagge, northern Sweden, which originated from a series of individual events. He ranked sediment transport by avalanches second after debris flows, but emphasized that for both types of mass movement, frequency and magnitude mostly govern their geomorphological significance (Rapp, 1960a). Ackroyd (1987) in the New Zealand Alps, and Bell et al. (1990) in the Himalayas, quantified sedimentation of single avalanche events. Ackroyd observed the redeposition of large boulders by avalanches, and Bell et al. (1990) estimated the sedimentation to be 0.74 and $0.21 \mathrm{~mm}$ after two avalanches. Heckmann et al. (2002, 2005) quantified and modeled the contribution of avalanches to the sediment balance of two alpine catchment areas for two years in the Bavarian Alps. They concluded that avalanches contributed significantly to the sediment balance and relief development of high-mountain areas. Most recently, Sass et al. (2010) calculated rockwall retreat rates by avalanche sedimentation based on a $6 \mathrm{yr}$ record in the Tyrolean Alps, documenting rates of $4-5 \mathrm{~mm} \mathrm{yr}^{-1}$.

\subsection{High Arctic Svalbard perspective}

In Svalbard the dynamics of rockwall weathering, talus formation and avalanche sedimentation have been studied by Rapp (1960a), Jahn (1967, 1976, 1984), Åkerman (2005, 1984) and André (1990, 1995, 1996, 1997), and most recently by Humlum et al. (2007) and Siewert et al. (2012). Åkerman (1984) and André (1990) assigned high erosional significance to full-depth slush avalanches and dirty spring avalanches. André (1990, 1996), however, did not find evidence for significant avalanche sediment erosion but only slight reshaping of talus, in schist and gneissic bedrock. Also, Jahn (1976) ascribed only minor importance to avalanches for the overall slope denudation in the Longyeardalen valley. However, Humlum et al. (2007) found that cornice fall avalanche sedimentation enabled the development of a rock glacier during the Holocene. Mean rock debris accumulation rates, quantified by direct measurements with permanently installed sediment traps, through two years, ranged from 0 to $50.4 \mathrm{~kg} \mathrm{~m}^{-2} \mathrm{yr}^{-1}$, averaging $13 \mathrm{~kg} \mathrm{~m}^{-2} \mathrm{yr}^{-1}$ on a northwestfacing slope (Humlum et al., 2007). Siewert et al. (2012) estimated Holocene rockwall retreat rates using electrical resistivity tomography (ERT) to quantify the volume of the talus deposits. Their results showed that rockwall retreat was $100 \%$ higher on northwest-facing slopes with cornice fall avalanche activity compared to southeast-facing slopes without. Snow cornices have been found to largely control plateau edge erosion in the Longyeardalen valley by favoring rock weathering by ice segregation, as well as mechanical plucking of the weathered sediment from the ridge (Eckerstorfer et al., 2013).

\subsection{Objective of the study}

Based on previous periglacial slope process studies from the Longyeardalen valley (Eckerstorfer et al., 2013; Siewert et al., 2012; Humlum et al., 2007), cornice fall avalanche sedimentation is of geomorphologic significance. Yet, a detailed quantification of avalanche sedimentation causing the formation of well-defined avalanche fans has never been performed. Only a few field studies have quantified the geomorphological effect of avalanche sedimentation, and such studies are particularly rare from High Arctic environments. We therefore combine monitoring of cornice fall activity with automatic time-lapse photography and field observations by directly measuring mean rock debris sedimentation rates $\left(\mathrm{kg} \mathrm{m}^{-2} \mathrm{yr}^{-1}\right)$, and using these numbers for upscaling and calculating avalanche sedimentation $\left(\mathrm{kg} \mathrm{yr}^{-1}\right)$, as well as avalanche accretion rates $\left(\mathrm{mm} \mathrm{yr}^{-1}\right)$ and rockwall retreat rates $\left(\mathrm{mm} \mathrm{yr}^{-1}\right)$. This way we quantify the geomorphological effect of cornice fall avalanche activity. We define avalanche sedimentation as the deposition of rock debris by avalanches leading to the formation of distinct avalanche fans. The rock debris being accumulated this way is transported downslope by collapsing cornices and/or cornice fall avalanches, and can be of different origin, following Sass et al. (2010). The work has also a slope-hazard-related perspective, as on the lower parts of the Nybyen slope system, housing infrastructure is built on the avalanche fans. Thus, improved geomorphological slope process understanding is important.

\section{Study area and climate}

Large parts of the landscape in central Svalbard are periglacial, with only minor glaciation. Both the Nybyen and the Larsbreen slope systems (Fig. 1) (hereafter called Nybyen and Larsbreen) are situated within the same bedrock region of near horizontal sedimentary layers of sandstones and shales in the Van Mijenfjorden Group, lower Tertiary age (Hjelle, 1993). This geological setting forms extensive plateau mountain topography, and favors, in combination 


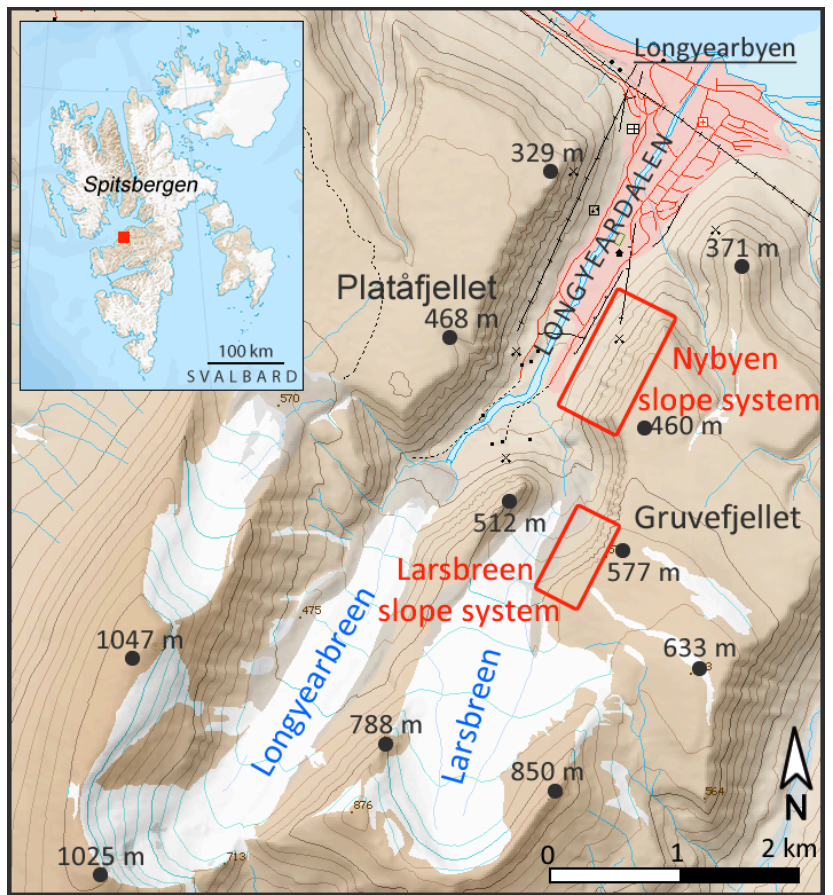

Fig. 1. Topographic map of the location of the two slope systems (red boxes) in the valley Longyeardalen in central Spitsbergen (inset map). Svalbard's main settlement, Longyearbyen, is located at the northern end of Longyeardalen. Note the large summit plateau of Gruvefjellet Mountain.

with snow transport by prevailing winds from the SE, the formation of cornices on lee sides (Eckerstorfer and Christiansen, 2011; Vogel et al., 2012; Eckerstorfer et al., 2013). These cornices form annually due to a large fraction of precipitation falling as snow. The mean annual precipitation (MAP) was $196 \mathrm{~mm}$ water equivalent (w.e.) in the 1912 2012 period (Met.no, 2013). Mean annual air temperature (MAAT) for the $100 \mathrm{yr}$ period was $-6^{\circ} \mathrm{C}$, rising since the 1960s towards a MAAT of $-3.4^{\circ} \mathrm{C}$ in 2011. MAAT for the 1960-2010 period was $-5.6^{\circ} \mathrm{C}$ (Met.no, 2013).

\section{Methods}

\subsection{Geomorphological mapping}

To determine past and present slope activity, sediment cover and landforms, detailed geomorphological mapping was carried out. Mapping is based on stereo analysis of aerial photographs and subsequent field investigations to verify the remote sensing analysis and clarify uncertainties.

\subsection{Avalanche activity monitoring}

Seasonal avalanche activity was monitored by field observations and automatic time-lapse photography (Christiansen, 2001; Vogel et al., 2012) (Supplement Fig. 1). Monitoring started in 2003/2004 at Larsbreen and 2007/2008 at Nybyen (Fig. 2). Periods without photo coverage were mainly due to technical problems with the camera, bad visibility or darkness during the polar night (Fig. 2). At least one daily photograph, but ranging up to six, was taken of the Nybyen and Larsbreen slope system. Additionally, one daily photograph was taken of the catchments L1-L3 at Larsbreen (Lars-cam) (Supplement Fig. 1). All Nybyen catchments were monitored between 2007/2008 and 2010/2011. At Larsbreen, avalanche monitoring started in 2003/2004 in catchments L2 and L3, both having the longest records, with L2 having $7 \mathrm{yr}$ and L3 6 yr. No observation and sampling took place in 2004/2005 on Larsbreen (Fig. 2). Therefore, rock debris sampled in catchment L3 in 2006/2007 is from two years of debris deposition.

Data on date and time of release of each avalanche, location of release (number of catchment) and extent was stored in a database. Only avalanches that reached the primary fan were included in the calculations. The visible rock debris content, estimated in situ, or from the time-lapse photographs was classified into three classes: "no visible rock debris", "some visible rock debris" and "high amounts of visible rock debris", corresponding to $>75 \%,>50 \%$ and $<25 \%$ of the avalanche snow-deposit area covered with visible rock content, respectively.

\subsection{Avalanche sedimentation}

Avalanche sedimentation $\left(\mathrm{kg} \mathrm{yr}^{-1}\right)$ (Table 1f) was directly measured in avalanche deposited rock debris from sediment or snow traps $(\mathrm{kg})$ (Table 1c) and upscaled by the maximum area of avalanche snow deposition $\left(\mathrm{m}^{2}\right)$ (Table $1 \mathrm{~b}$ ). In two catchments (L2 and L3) at Larsbreen, four $16 \mathrm{~m}^{2}$ large plastic squares were installed in 2003/2004 (T1 to T4 in Supplement Fig. 2a, b). These squares were anchored along the entire periphery with a line of boulders and emptied each year at the end of summer, typically in September (Fig. 2). At this time of the summer, the deposited avalanche snow had melted enough to make the plastic sheets partly or fully visible. In some years, the plastic sheets had to be replaced due to holes in them, and the sediment traps needed to be slightly moved. Additionally, in catchment L2, a large, flattopped boulder (T5 in Supplement Fig. 2a, c) was used as another sediment trap, also only cleared in September each year.

Furthermore, rock debris quantification based on snow surface inventories (snow traps) (Luckman, 1978a) has also been carried out in all catchments at both sites since 2007/2008. These were done when the rock debris, during snowmelt had concentrated on the snow surface, with a still intact boundary of snow to the avalanche fan surface of the previous year below (Supplement Fig. 2d). These snow inventories were on average 4-8 $\mathrm{m}^{2}$ (Supplement Fig. 2e), and were located at the furthest possible downslope locations on the avalanche fans. All catchments at Nybyen were sampled 


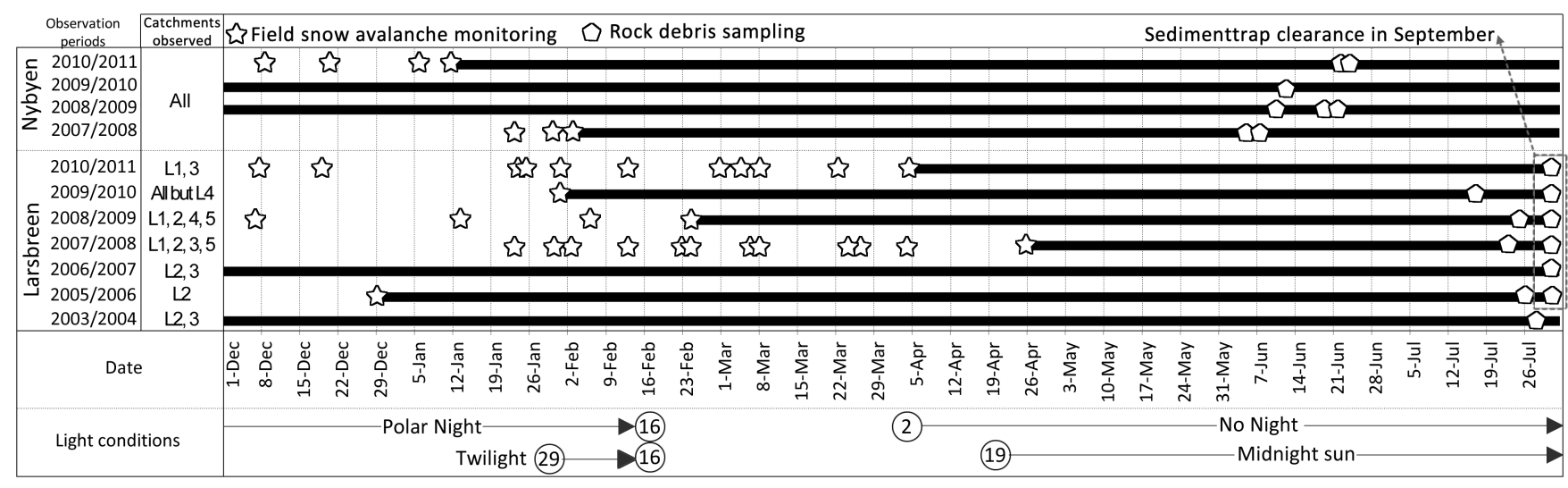

Fig. 2. Timing of annual avalanche monitoring and rock sediment collection for each slope system. The black lines indicate periods with daily automatic time-lapse photography. The stars indicate field avalanche monitoring on-site, and the pentagons indicate rock sediment collection on avalanche snow deposits. The sediment traps at the Larsbreen catchments were all emptied in early September between 2005/2006 and 2010/2011. In the lower part of the figure, light conditions are indicated with the date (number in circle) when seasonal changes occur.

in June each year (Fig. 2), as snow melting occurred earlier than at the higher located Larsbreen site, where sampling took place in July or September. The rock debris in each sampling parcel or in the permanent sediment traps was weighed in a bag using a hand scale. The weight of small fragments was estimated visually, and the sum of all rock debris was rounded to the nearest full $\mathrm{kg}$. Large, heavy boulders were hammered into smaller pieces for weighing.

\subsection{Avalanche fan-surface accretion and rockwall retreat rates}

We have used the obtained mean rock debris sedimentation rates $\left(\mathrm{kg} \mathrm{m}^{-2} \mathrm{yr}^{-1}\right)$ (Table 1e) for upscaling to determine the entire avalanche sedimentation both as mass $\left(\mathrm{kg} \mathrm{yr}^{-1}\right)$ (Table 1f) and as the mean avalanche fan-surface accretion rates $\left(\mathrm{mm} \mathrm{yr}^{-1}\right)$ (Table $2 \mathrm{~b}$ ) for both the Nybyen and Larsbreen sites. We also use the entire avalanche sedimentation amounts (Table 1f) for assessing average rockwall retreat rates $\left(\mathrm{mm} \mathrm{yr}^{-1}\right)$ (Table $\left.2 \mathrm{c}\right)$. All these numbers have been measured and calculated for each sub catchment in both the Nybyen and Larsbreen sites (Table 1, Table 2). The numbers were only calculated for a particular sub catchment and year if avalanche activity was recorded and rock debris deposition was directly measured (Fig. 2). Annually, the maximum area of avalanche snow deposition $\left(\mathrm{m}^{2}\right)$ per catchment (Table $1 b$ ) was obtained by digitizing the avalanche outlines in ArcGIS 10, using a digital elevation model with $2 \mathrm{~m}$ spatial resolution. Directly measured avalanche-deposited rock debris from sediment or snow traps $\left(\mathrm{kg} \mathrm{yr}^{-1}\right)$ (Table 1c) were derived from summing the amounts of rock debris weighed in each sediment or snow trap of each sub catchment. Mean rock debris sedimentation rates $\left(\mathrm{kg} \mathrm{m}^{-2} \mathrm{yr}^{-1}\right)$ (Table 1e) were obtained by dividing the amount of directly measured avalanche deposited rock debris from sediment or snow traps $\left(\mathrm{kg} \mathrm{yr}^{-1}\right)$ (Table 1c) by the size of rock debris collection area in sediment or snow traps $\left(\mathrm{m}^{2}\right)$ (Table 1d). Avalanche sedimentation $\left(\mathrm{kg} \mathrm{yr}^{-1}\right)$ (Table 1f) was calculated by multiplying the maximum area of avalanche snow deposition $\left(\mathrm{m}^{2}\right)$ (Table $\left.1 \mathrm{~b}\right)$ with the mean rock debris sedimentation rate $\left(\mathrm{kg} \mathrm{m}^{-2} \mathrm{yr}^{-1}\right)$ (Table 1e).

To calculate avalanche fan-surface accretion rates $\left(\mathrm{mm} \mathrm{yr}^{-1}\right)$ (Table $\left.2 \mathrm{~b}\right)$ and rockwall retreat rates $\left(\mathrm{mm} \mathrm{yr}^{-1}\right)$ (Table 2c), the avalanche rock debris volume $\left(\mathrm{m}^{3} \mathrm{yr}^{-1}\right)$ (Table 2a) had to be calculated by dividing avalanche sedimentation $\left(\mathrm{kg} \mathrm{yr}^{-1}\right)$ (Table 1f) by the mean rock density of $2250 \mathrm{~kg} \mathrm{~m}^{-3}$. This value was measured by Siewert et al. (2012) in the laboratory on sandstone rock samples from the study area. To correct the volume, density was multiplied with a correction factor of 0.65 to compensate for the difference of the lower talus bulk density compared to intact higher bedrock density (Siewert et al., 2012). Dividing the avalanche rock debris volume $\left(\mathrm{m}^{3} \mathrm{yr}^{-1}\right)$ (Table 2a) by the maximum area of avalanche snow deposition $\left(\mathrm{m}^{2}\right)$ (Table 1b) enabled calculation of avalanche fan-surface accretion rates $\left(\mathrm{mm} \mathrm{yr}^{-1}\right)$ (Table $\left.2 \mathrm{~b}\right)$. Likewise, by dividing the total avalanche rock debris volume $\left(\mathrm{m}^{3}\right)$ (Table $2 \mathrm{a}$ ) by the area of the rockwall (source areas) $\left(\mathrm{m}^{2}\right)$ (Supplement Table 2), rockwall retreat rates $\left(\mathrm{mm} \mathrm{yr}^{-1}\right)$ (Table $2 \mathrm{c}$ ) were determined, assuming all debris came originally directly from the backwall (see later discussion on possible errors, Sect. 5.3). The source and depositional areas are marked in Fig. 3b with a white outline, separated by the green dashed line. In Fig. $4 \mathrm{~b}$ the source and depositional areas are also marked with a white outline, separated by the yellow dashed line. The source and depositional areas and the area of the annual maximum area of avalanche snow deposition $\left(\mathrm{m}^{2}\right)$ (Table 1b) were mapped in ArcGIS 10 using the "3-D analyst" tool "interpolate polygon to multipatch" to receive the area of the three-dimensionally delimited landforms, as opposed to a planimetric area. 
Table 1. All calculations to obtain avalanche sedimentation $\left(\mathrm{kg} \mathrm{yr}^{-1}\right)$ for each catchment at the Nybyen (N1-N5) and Larsbreen (L1-L7) slope systems. The annual averages or sums for Nybyen and Larsbreen are given in bold. The highest values and rates for each calculation step are given in italic. The values and rates marked with an asterisk are from $2 \mathrm{yr}$ of observations. Avalanche sedimentation values $\left(\mathrm{kg}^{\mathrm{yr}} \mathrm{r}^{-1}\right)$ from Larsbreen, which are underlined, are only calculated from permanent sediment traps.

\begin{tabular}{rrrrrrrrrrr}
\hline $2007 /$ & $2008 /$ & $2009 /$ & $2010 /$ & $2003 /$ & $2005 /$ & $2006 /$ & $2007 /$ & $2008 /$ & $2009 /$ & $2010 /$ \\
2008 & 2009 & 2010 & 2011 & 2004 & 2006 & 2007 & 2008 & 2009 & 2010 & 2011 \\
\hline
\end{tabular}

\begin{tabular}{|c|c|c|c|c|c|c|c|c|c|c|c|c|}
\hline \multicolumn{13}{|c|}{ (a) Number of avalanches per catchment $(\mathrm{N})$} \\
\hline N1 & 2 & 2 & & & L1 & & & & 5 & 4 & 7 & 5 \\
\hline $\mathrm{N} 2$ & & & 6 & 3 & L2 & 2 & 4 & 5 & 4 & 5 & 10 & 8 \\
\hline N3 & & & & 2 & L3 & 2 & & 5 & 4 & 7 & 10 & 7 \\
\hline N4 & & 4 & & 2 & L4 & & & & & 3 & & \\
\hline \multirow[t]{4}{*}{ N5 } & 4 & & 7 & & L5 & & & & 5 & & 3 & \\
\hline & & & & & L6 & & & & & & 7 & \\
\hline & & & & & L7 & & & & & & 3 & \\
\hline & 6 & 6 & 13 & 7 & & 4 & 4 & 10 & 18 & 19 & 40 & 20 \\
\hline
\end{tabular}

(b) Maximum area of avalanche snow deposition $\left(\mathrm{m}^{2}\right)$

\begin{tabular}{llllllllllllll}
\hline N1 & 26894 & 27508 & & & L1 & & & & 6989 & 6168 & 6884 & 7106 \\
N2 & & & 9482 & 13948 & L2 & 7209 & 7490 & 6811 & 6186 & 7241 & 7932 & 8567 \\
N3 & & & & 18822 & L3 & 4564 & & 4877 & 4088 & 6487 & 5698 & 7653 \\
N4 & & 14955 & & 21844 & L4 & & & & & 5123 & & \\
N5 & 15944 & & 11640 & & L5 & & & & 8183 & & 2685 & \\
& & & & & L6 & & & & & & 4896 & \\
& & & & & L7 & & & & & & 3218 & \\
& $\mathbf{4 2 8 3 8}$ & $\mathbf{4 2 4 6 3}$ & $\mathbf{2 1 1 2 2}$ & $\mathbf{5 4 6 1 4}$ & & $\mathbf{1 1 7 7 3}$ & $\mathbf{7 4 9 0}$ & $\mathbf{1 1 6 8 8}$ & $\mathbf{2 5 4 4 6}$ & $\mathbf{2 5 0 1 9}$ & $\mathbf{3 1 3 1 3}$ & $\mathbf{2 3 3 2 6}$
\end{tabular}

(c) Directly measured avalanche deposited rock debris from sediment or snow traps $\left(\mathrm{kg} \mathrm{yr}^{-1}\right)$

\begin{tabular}{|c|c|c|c|c|c|c|c|c|c|c|c|c|}
\hline N1 & 290 & 1801 & & & L1 & & & & 160 & 147 & 225 & 587 \\
\hline $\mathrm{N} 2$ & & & 619 & 467 & L2 & 209 & 368 & 74 & 544 & 651 & 11135 & 717 \\
\hline N3 & & & & 669 & L3 & 144 & & *328 & 73 & 207 & 632 & 530 \\
\hline N4 & & 201 & & 967 & L4 & & & & & 443 & & \\
\hline \multirow[t]{4}{*}{ N5 } & 298 & & 685 & & L5 & & & & 98 & & 120 & \\
\hline & & & & & L6 & & & & & & 370 & \\
\hline & & & & & L7 & & & & & & 220 & \\
\hline & 588 & 2002 & 1304 & 2103 & & 352 & 368 & 402 & 875 & 1448 & 12702 & 1834 \\
\hline
\end{tabular}

(d) Size of rock debris collection area in sediment or snow traps $\left(\mathrm{m}^{2}\right)$

\begin{tabular}{rrrrrrrrrrrrr}
\hline N1 & 32 & 220 & & & L1 & & & & 8 & 11 & 16 & 16 \\
N2 & & & 16 & 25 & L2 & 54 & 36 & 90 & 44 & 26 & 543 & 36 \\
N3 & & & & 25 & L3 & 36 & & $* 90$ & 8 & 18 & 34 & 32 \\
N4 & & 12 & & 30 & L4 & & & & & 8 & \\
N5 & 20 & & 28 & & L5 & & & & 8 & & 4 & 12 \\
& & & & & L6 & & & & & & 16 & $\mathbf{6 2 5}$ \\
& $\mathbf{5 8}$ & $\mathbf{2 3 2}$ & $\mathbf{4 4}$ & $\mathbf{8 0}$ & & $\mathbf{9 0}$ & $\mathbf{3 6}$ & $\mathbf{1 8 0}$ & $\mathbf{6 8}$ & $\mathbf{6 3}$ & $\mathbf{6 4}$ \\
\hline
\end{tabular}

(e) Directly measured avalanche deposited rock debris from sediment or snow traps $\left(\mathrm{kg} \mathrm{yr}^{-1}\right) / \mathrm{size}$ of rock debris collection area from sediment or snow traps $\left(\mathrm{m}^{2}\right)=$ mean rock debris sedimentation rate $\left(\mathrm{kg} \mathrm{m}^{-2} \mathrm{yr}^{-1}\right)$

\begin{tabular}{rrrrrrrrrrrrr}
\hline N1 & 9.1 & 8.2 & & & L1 & & & & 20.0 & 13.4 & 14.1 & 36.7 \\
N2 & & & 38.7 & 18.7 & L2 & 3.9 & 10.2 & 0.8 & 12.4 & 25.0 & 20.5 & 19.9 \\
N3 & & & & 26.8 & L3 & 4.0 & & $* 3.6$ & 9.1 & 11.5 & 18.6 & 16.6 \\
N4 & & 16.8 & & 32.2 & L4 & & & & & 55.4 & & \\
N5 & 14.9 & & 24.5 & & L5 & & & & 12.3 & & 30.0 & 30.8 \\
& & & & & L6 & & & & & & 13.8 & \\
& & & & & L7 & & & & & $\mathbf{2 1 . 8}$ \\
& $\mathbf{1 1 . 3}$ & $\mathbf{8 . 6}$ & $\mathbf{2 9 . 6}$ & $\mathbf{2 6 . 3}$ & & $\mathbf{3 . 9}$ & $\mathbf{1 0 . 2}$ & $\mathbf{2 . 2}$ & $\mathbf{1 2 . 9}$ & $\mathbf{2 3 . 0}$ & $\mathbf{2 0 . 3}$ & $\mathbf{2 1 . 0}$ \\
\hline
\end{tabular}


Table 1. Continued.

\begin{tabular}{|c|c|c|c|c|c|c|c|c|c|c|c|c|}
\hline & $\begin{array}{r}2007 / \\
2008\end{array}$ & $\begin{array}{r}2008 / \\
2009\end{array}$ & $\begin{array}{r}2009 / \\
2010\end{array}$ & $\begin{array}{r}2010 / \\
2011\end{array}$ & & $\begin{array}{r}2003 / \\
2004\end{array}$ & $\begin{array}{r}2005 / \\
2006\end{array}$ & $\begin{array}{r}2006 / \\
2007\end{array}$ & $\begin{array}{r}2007 / \\
2008\end{array}$ & $\begin{array}{r}2008 / \\
2009\end{array}$ & $\begin{array}{r}2009 / \\
2010\end{array}$ & $\begin{array}{r}2010 / \\
2011\end{array}$ \\
\hline \multicolumn{13}{|c|}{ (f) Maximum area of avalanche snow deposition $\left(\mathrm{m}^{2}\right)$} \\
\hline N1 & 243727 & 225190 & & & L1 & & & & 139780 & 82427 & 96806 & 260701 \\
\hline $\mathrm{N} 2$ & & & 366835 & 260549 & $\mathrm{~L} 2$ & 27835 & 76502 & 5615 & 76481 & 181304 & 162651 & 170626 \\
\hline N3 & & & & 503677 & L3 & $\overline{18218}$ & & $* 1 \overline{755}$ & 37303 & $\underline{74601}$ & 105916 & $\overline{126753}$ \\
\hline N4 & & 250496 & & 704105 & $\mathrm{~L} 4$ & & & & & $2 \overline{83686}$ & & \\
\hline \multirow[t]{4}{*}{ N5 } & 237566 & & 284764 & & L5 & & & & 100242 & & 80550 & \\
\hline & & & & & L6 & & & & & & 150960 & \\
\hline & & & & & L7 & & & & & & 44248 & \\
\hline & 484399 & 366426 & 625979 & 1435666 & & 46072 & 76502 & 26093 & 327430 & 575040 & 636360 & 509284 \\
\hline
\end{tabular}

Table 2. Calculations of avalanche fan-surface accretion and rockwall retreat rates $\left(\mathrm{mm} \mathrm{yr}^{-1}\right)$ for each catchment at the Nybyen (N1-N5) and Larsbreen (L1-L7) slope systems. The source and depositional areas for each catchment are visualized in Figs. 3 and 4 with the white outline and in Supplement Table 2. The annual averages for Nybyen and Larsbreen are given in bold. The highest values and rates for each calculation step are given in italic. The values and rates marked with an asterisk are from $2 \mathrm{yr}$ of observations. The underlined rates from Larsbreen are only calculated from permanent sediment traps.

\begin{tabular}{|c|c|c|c|c|c|c|c|c|c|c|c|c|}
\hline & $\begin{array}{r}2007 / \\
2008\end{array}$ & $\begin{array}{r}2008 / \\
2009\end{array}$ & $\begin{array}{r}2009 / \\
2010\end{array}$ & $\begin{array}{r}2010 / \\
2011\end{array}$ & & $\begin{array}{r}2003 / \\
2004\end{array}$ & $\begin{array}{r}2005 / \\
2006\end{array}$ & $\begin{array}{c}2006 / \\
2007\end{array}$ & $\begin{array}{r}2007 / \\
2008\end{array}$ & $\begin{array}{r}2008 / \\
2009\end{array}$ & $\begin{array}{r}2009 / \\
2010\end{array}$ & $\begin{array}{r}2010 / \\
2011\end{array}$ \\
\hline \multicolumn{13}{|c|}{$\begin{array}{l}\text { (a) Avalanche sedimentation }\left(\mathrm{kg} \mathrm{yr}^{-1}\right) / \text { mean rock density of } 2250 \mathrm{~kg} \mathrm{~m}^{-3} \\
{ }^{*} 0.65 \text { volume correction }=\text { avalanche rock debris volume }\left(\mathrm{m}^{3} \mathrm{yr}^{-1}\right)\end{array}$} \\
\hline N1 & 70.4 & 65.1 & & & $\mathrm{~L} 1$ & & & & 40.4 & 23.8 & 27.9 & 75.3 \\
\hline N2 & & & 105.8 & 75.3 & L2 & 8.0 & 22.1 & 1.6 & 22.1 & 52.4 & 47.9 & 49.3 \\
\hline N3 & & & & 145.5 & L3 & 5.3 & & $* 5.1$ & 10.8 & 21.6 & 30.6 & 36.6 \\
\hline N4 & & 72.4 & & 203.4 & L4 & & & & & 81.9 & & \\
\hline \multirow[t]{4}{*}{ N5 } & 68.6 & & 82.3 & & L5 & & & & 29.0 & & 23.3 & \\
\hline & & & & & L6 & & & & & & 43.6 & \\
\hline & & & & & L7 & & & & & & 12.8 & \\
\hline & 139.9 & 105.9 & 180.8 & 414.8 & & 13.3 & 22.1 & 7.5 & 94.6 & 166.1 & 183.9 & 147.1 \\
\hline \multicolumn{13}{|c|}{ (b) Avalanche fan-surface accretion rate $\left(\mathrm{mm} \mathrm{yr}^{-1}\right)$} \\
\hline N1 & 2.6 & 2.4 & & & L1 & & & & 5.6 & 3.3 & 3.9 & 10.3 \\
\hline N2 & & & 4.9 & 3.4 & L2 & $\underline{0.9}$ & $\underline{0.5}$ & $\underline{0.2}$ & 2.6 & $\underline{6.1}$ & 5.5 & 5.7 \\
\hline N3 & & & & 6.8 & L3 & $\underline{0.7}$ & & $\overline{0.7}$ & 1.4 & $\overline{2.8}$ & 3.9 & $\underline{4.7}$ \\
\hline N4 & & 3.1 & & 8.8 & L4 & & & & & 13.9 & & \\
\hline \multirow[t]{4}{*}{ N5 } & 3.7 & & 4.4 & & L5 & & & & 3.4 & & 2.8 & \\
\hline & & & & & L6 & & & & & & 7.5 & \\
\hline & & & & & L7 & & & & & & 3.3 & \\
\hline & 1.2 & 0.9 & 1.6 & 3.7 & & 0.05 & 0.1 & 0.2 & 2.0 & 3.5 & 3.9 & 3.1 \\
\hline \multicolumn{13}{|c|}{ (c) Rockwall retreat rate $\left(\mathrm{mm} \mathrm{yr}^{-1}\right)$} \\
\hline N1 & 0.6 & 0.6 & & & L1 & & & & 0.8 & 0.4 & 0.5 & 1.4 \\
\hline N2 & & & 0.8 & 0.6 & $\mathrm{~L} 2$ & $\underline{0.2}$ & $\underline{0.5}$ & $\underline{0.04}$ & 0.5 & $\underline{1.2}$ & 1.1 & 1.2 \\
\hline N3 & & & & 0.9 & L3 & $\underline{0.2}$ & & $\underline{0.2}$ & 0.4 & 0.9 & 1.2 & $\underline{1.5}$ \\
\hline N4 & & 0.3 & & 0.9 & L4 & & & & & 1.3 & & \\
\hline \multirow[t]{4}{*}{ N5 } & 0.5 & & 0.6 & & L5 & & & & 0.6 & & 0.5 & \\
\hline & & & & & L6 & & & & & & 6.7 & \\
\hline & & & & & L7 & & & & & & 1.0 & \\
\hline & 0.2 & 0.2 & 0.3 & 0.6 & & 0.05 & 0.5 & 0.03 & 0.4 & 0.7 & 0.7 & 0.6 \\
\hline
\end{tabular}




\section{Results}

\subsection{The geomorphology of the Nybyen and Larsbreen slope systems}

The Nybyen slope system consists of a multi-stepped erosion, transport and sedimentation system with a vertical relief of $300 \mathrm{~m}$, and a $1000 \mathrm{~m}$ long horizontal ridgeline (Fig. 3). The detailed geomorphological description of the Nybyen slope system is presented in Supplement Table 1. The most prominent periglacial landforms are the highly weathered plateau edge that transitions softly into the free vertical rock face. Below, a layer of rockfall and avalanche deposits covers a first depositional area $\left(40-50^{\circ}\right)$, which transitions into transport couloirs between protruding rock noses $\left(35-45^{\circ}\right)$. These couloirs are primarily erosional landforms with only a thin sediment cover, leading down to the primary avalanche fans $\left(20-45^{\circ}\right)$. These have a concave cross-curvature and a bimodal rock composition. The lowermost slope deposits (5$15^{\circ}$ ) have debris and slush flow levees imprinted, currently not active.

The Larsbreen slope system is between 130 and $160 \mathrm{~m}$ high, and about $600 \mathrm{~m}$ long. The varying height is due to some variation in plateau height, but primarily because the foot of the slope system is based at the lateral moraine of Larsbreen Glacier (Fig. 4), which acts as a topographical barrier. Hence, the slope deposits extend onto the ice-cored moraines (Etzelmueller et al., 2000). The slope system is relatively simple, with avalanches and rockfalls as the predominant transport processes, and a clear connection between erosional and depositional areas, with no long-term intermediate storage. However, it consists also of a weathered plateau edge, which is vertically above L4-L7. The free rock face gradually reduces in steepness downwards, covered by a thin sediment cover, and transitions directly into the primary avalanche fans $\left(15-45^{\circ}\right)$. These are visibly intermixed with snow and ice at depth. In the southernmost part (L6L7) individual fans are not distinguishable. A more detailed description of the landforms is presented in Supplement Table 1 .

\subsection{Cornice fall avalanche activity and rock debris quantification}

At both slope systems, all avalanches were exclusively cornice fall avalanches, releasing at minimum twice annually in all 13 catchments (Table 1a). Cornice fall avalanches were registered throughout the entire snow season, with a peak activity from May to July (Figs. $5 b$ and $6 b$ ). Only at the end of spring were the cornice fall avalanches full depth avalanches, incorporating rock debris of different origin in the transport couloirs, when sweeping through. However, collapsing cornices frequently cleared the free rock face from rock debris during midwinter. Thus, rockfall deposits from the rock face are transported downslope together with avalanche deposits during the entire winter, while the transport couloirs are primarily swept in late spring.

At Nybyen, 77 avalanches were recorded during the observation period 2007/2008-2010/2011. Rock debris (Table 1c) was quantified in $41.5 \%$ (32 avalanches) of all avalanches. In $60 \%$ of the 32 avalanches studied, the debris terminus reached the lower third of the primary fans, $37 \%$ reached the middle third and $3 \%$ stopped in the upper third of the maximum runout zone (white line, Fig. 3b). Of all avalanches, $97 \%$ had visible rock debris in their avalanche deposits, while $68 \%$ of them had high amounts of visible rock debris ( $>75 \%$ of the avalanche snow-deposit area covered with rock debris). This shows that due to plucking of weathered rock debris by cornices (Eckerstorfer et al., 2013) as well as frequent clearing of the free rock face by avalanches, socalled "dirty" avalanches are produced throughout the entire snow season. This is exemplified by a cornice fall avalanche that released in March 2011 in catchment L4 (Fig. 5b), where high amounts of visible rock debris in the avalanche deposits cannot have originated from its slide path, being still covered by snow.

The largest maximum extent of avalanche snow deposits (Table 1b) was measured in catchment N1 in 2007/2008 and 2008/2009 (Fig. 5), with over $26000 \mathrm{~m}^{2}$ in both years (Table 1b). Also in 2008/2009 and in catchment N1, the most extensive rock debris quantification with 28 snow inventories was performed (Fig. 5a), covering an area of $220 \mathrm{~m}^{2}$ (Table 1d). In all catchments during the entire observation period, a minimum of $12 \mathrm{~m}^{2}$ of snow inventories (Table 1d) was sampled.

At Larsbreen, from 2003/2004 to 2010/2011, with the exception of 2004/2005 (no observations), 120 avalanche deposits were analyzed (Fig. 6b). A total of 156 avalanches were recorded, and thus $77 \%$ of all avalanches are taken into account. However, not all catchments were sampled equally over the entire observation period, as done at $\mathrm{Ny}$ byen (Fig. 2). Of 120 avalanches, 55\% stopped in the lower third and $45 \%$ in the middle third of the maximum runout zone (white line, Fig. 4). Rock sediment was visible in $91 \%$ of all investigated deposits, with $66 \%$ having high amounts of visible rock debris $(>75 \%)$.

The maximum area of avalanche snow deposition (Table 1b) is comparably smaller at Larsbreen than at Nybyen (Supplement Table 2), due to the slope system being shorter in vertical height and slide distance. However, the largest avalanches in all catchments approached the maximum visible slope deposition extent, which is at present found on the ice-cored marginal moraine of Larsbreen Glacier (Fig. 6). The magnitude of the cornice fall avalanches at Larsbreen can also be exemplified by the rock debris depositions in the permanent sediment trap T5 in catchment L2. The large, flattopped boulder located furthermost down on the avalanche fan (Supplement Fig. 2a, c) was covered with rock debris, and thus sampled each year, except in 2007/2008. This indicates that avalanches must be the primary rock debris 


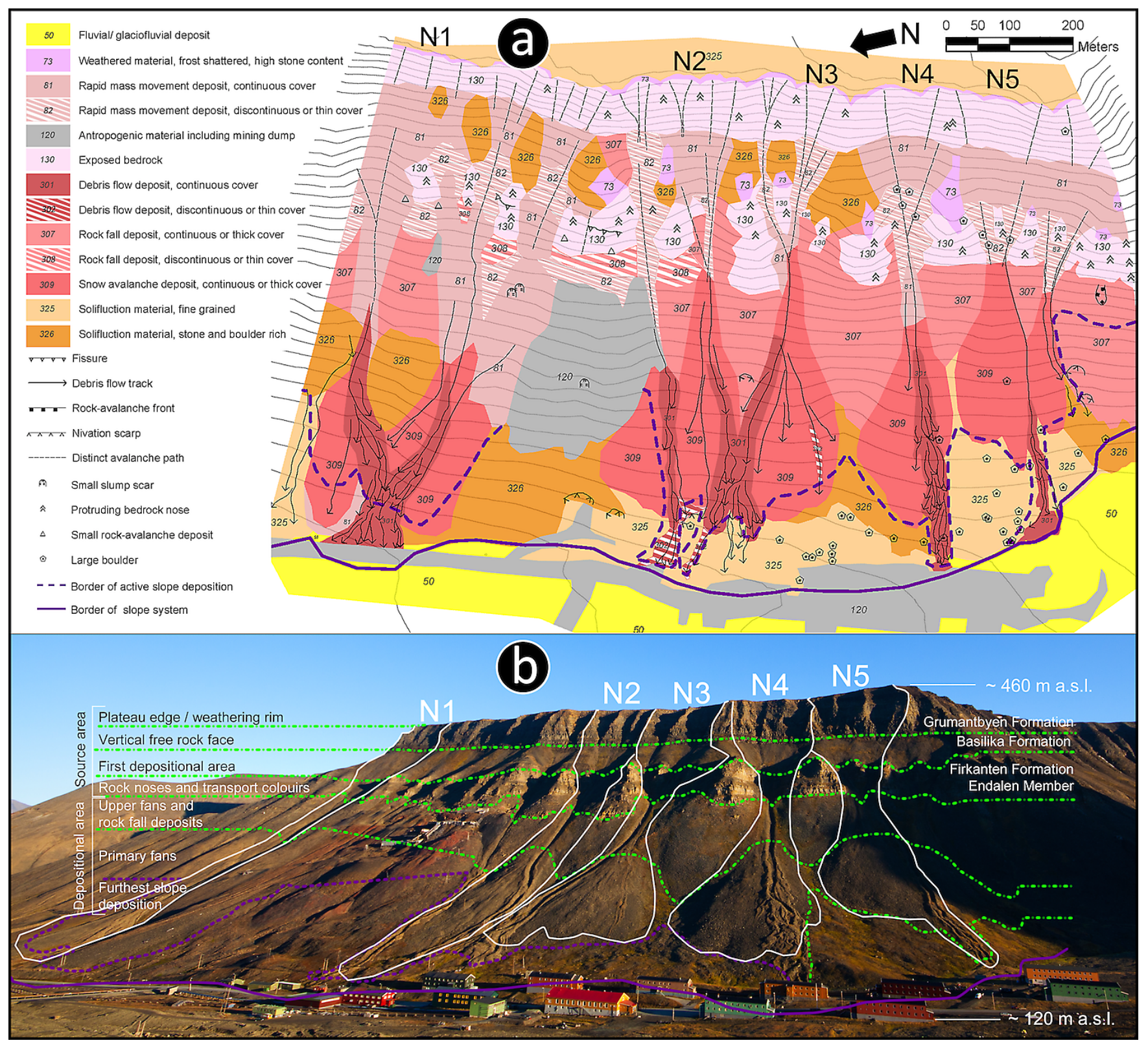

Fig. 3. (a) Geomorphology and sediments of the Nybyen slope system based on detailed geomorphological field mapping and 3-D aerial photogrammetry. (b) Nybyen with the five investigated catchments (N1-N5) (white line). The white line indicates the observed maximum modern runout distance of cornice fall avalanche sedimentation. The green dashed lines indicate different parts of the source and depositional areas or delimit the geological formations. The debris flow channels located in the overall depositional area are, however, erosional features. The purple line indicates the maximum extent of the slope deposits. Therefore, some of the infrastructure is built on slope deposits.

transport agent, as rockfalls are unlikely to move debris this far down on the avalanche fan and up onto a large boulder.

\subsection{Avalanche sedimentation rates}

Directly measured mean rock debris sedimentation rates $\left(\mathrm{kg} \mathrm{m}^{-2} \mathrm{yr}^{-1}\right)$ had a large interannual and intercatchment variability (Table 1e). In Nybyen, they ranged from 8.2 (N1 in $2008 / 2009)$ to $38.7 \mathrm{~kg} \mathrm{~m}^{-2} \mathrm{yr}^{-1}$ (N2 in 2009/2010). At
Larsbreen, these rates were as low as 0.8 (L2 in 2006/2007) and as high as $55.4 \mathrm{~kg} \mathrm{~m}^{-2} \mathrm{yr}^{-1}$ (L4 in 2008/2009). Upscaling these numbers, avalanche sedimentation $\left(\mathrm{kg} \mathrm{yr}^{-1}\right)$ ranged at Nybyen between 225190 (N1 in 2008/2009) and $704105 \mathrm{~kg} \mathrm{yr}^{-1}$ (N4 in 2010/2011) (Table 1f), and at Larsbreen from 5615 (L2 in 2006/2007) to $283686 \mathrm{~kg} \mathrm{yr}^{-1}$ (L4 in 2008/2009) (Table 1f). The directly measured avalanche sedimentation $\left(\mathrm{kg} \mathrm{yr}^{-1}\right)$ (Table 1f) is well correlated with the size of the maximum area of avalanche snow deposition 


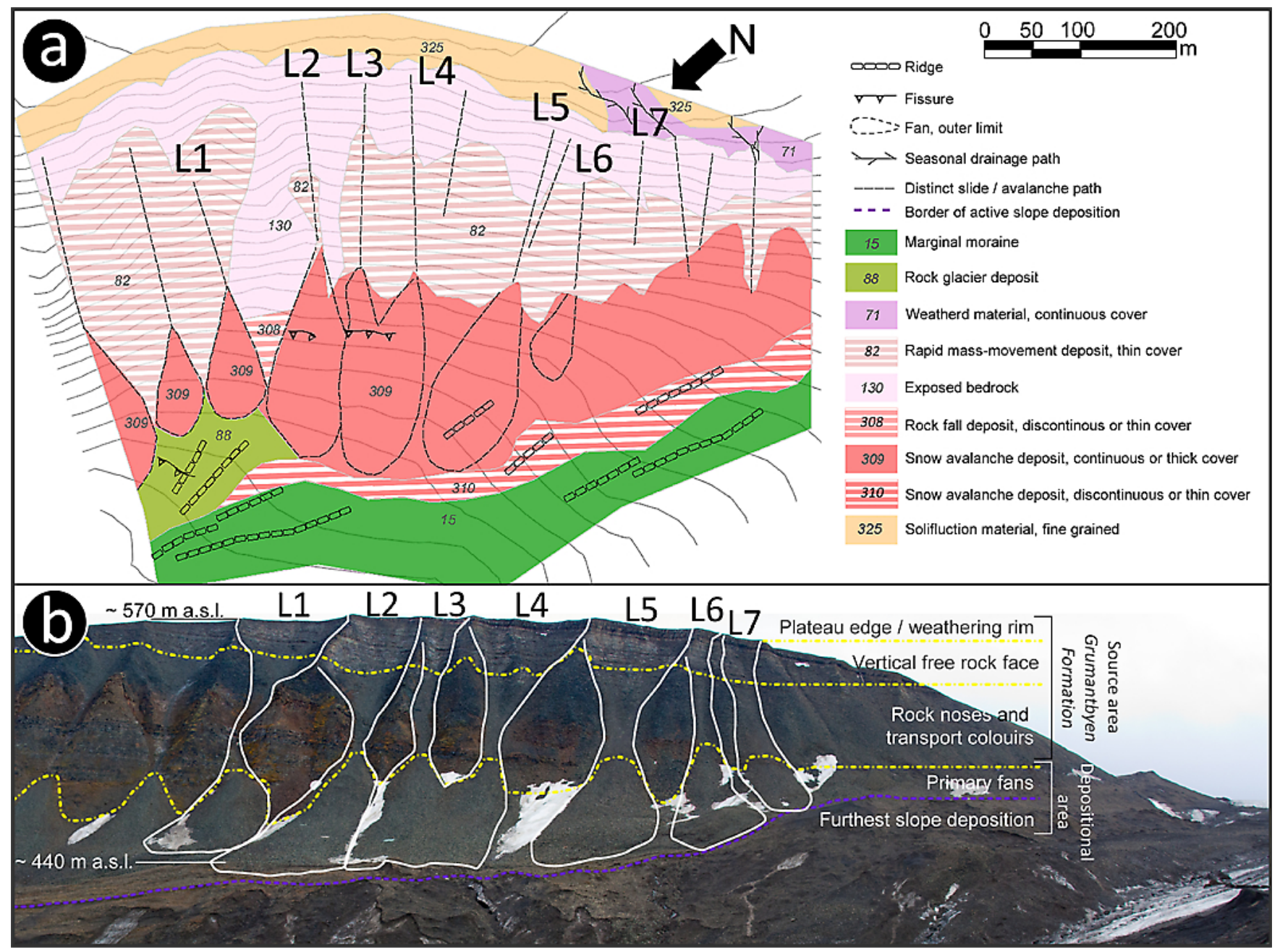

Fig. 4. (a) Geomorphology and sediments of the Larsbreen slope system based on detailed geomorphological field mapping and 3-D aerial photogrammetry. (a) Larsbreen with the seven catchments (L1-L7) (white line). The white lines indicate the maximum runout distance of cornice fall avalanches observed. The yellow dashed lines indicate different parts of the source and depositional areas or delimit the geological formations. The purple line indicates the maximum extent of the slope deposits.

$\left(\mathrm{m}^{2}\right)$ (Table 1b) at Larsbreen $\left(R^{2}=0.92\right)$ and Nybyen $\left(R^{2}=\right.$ $0.53)$. Somewhat weaker correlations were found between the calculated annual avalanche sedimentation $\left(\mathrm{kg} \mathrm{yr}^{-1}\right)$ (Table 1f) and directly measured avalanche deposited rock debris from sediment or snow traps $\left(\mathrm{kg} \mathrm{yr}^{-1}\right)$ (Table 1c), with $R^{2}=0.63$ at Larsbreen and $R^{2}=0.48$ at Nybyen.

\subsection{Avalanche fan-surface accretion and rockwall retreat rates}

At both slope systems, the interannual and intercatchment variability of avalanche fan-surface accretion rates $\left(\mathrm{mm} \mathrm{yr}^{-1}\right)$ and rockwall retreat rates $\left(\mathrm{mm} \mathrm{yr}^{-1}\right)$ is high (Table 2). Maximum avalanche fan-surface accretion rates were $8.8 \mathrm{~mm} \mathrm{yr}^{-1}$ at Nybyen (N4 in 2010/2011) and $13.9 \mathrm{~mm} \mathrm{yr}^{-1}$ at Larsbreen (L4 in 2008/2009) (Table 2b), both in the catchments with the largest source areas (Supplement Ta- ble 2). Maximum rockwall retreat rates at Nybyen were $0.9 \mathrm{~mm} \mathrm{yr}^{-1}$, also calculated in N4 in 2010/2011; at Larsbreen, however, the maximum of $6.7 \mathrm{~mm} \mathrm{yr}^{-1}$ was from catchment L6 in 2009/2010 (Table 2c). In general, at both slope systems on average, a larger maximum area of avalanche snow deposition $\left(\mathrm{m}^{2}\right)$ (Table $\left.1 \mathrm{~b}\right)$ led to higher avalanche fan-surface accretion rates (Table $2 \mathrm{~b}$ ) and rockwall retreat rates (Table 2c). Corresponding correlations are $R^{2}=0.94$ (for avalanche fan-surface accretion rates) and $R^{2}=0.71$ (for rockwall retreat rates) for Larsbreen, and $R^{2}=0.53$ (for avalanche fan-surface accretion rates) and $R^{2}=0.53$ (for rockwall retreat rates) for Nybyen, all significant at the 0.05 level. The somewhat lower correlations at Nybyen are presumably due to its more complex slope system, where source and depositional area are not directly connected but interrupted by the first depositional area (Fig. 3b). This is one reason why the larger source areas at Nybyen did 


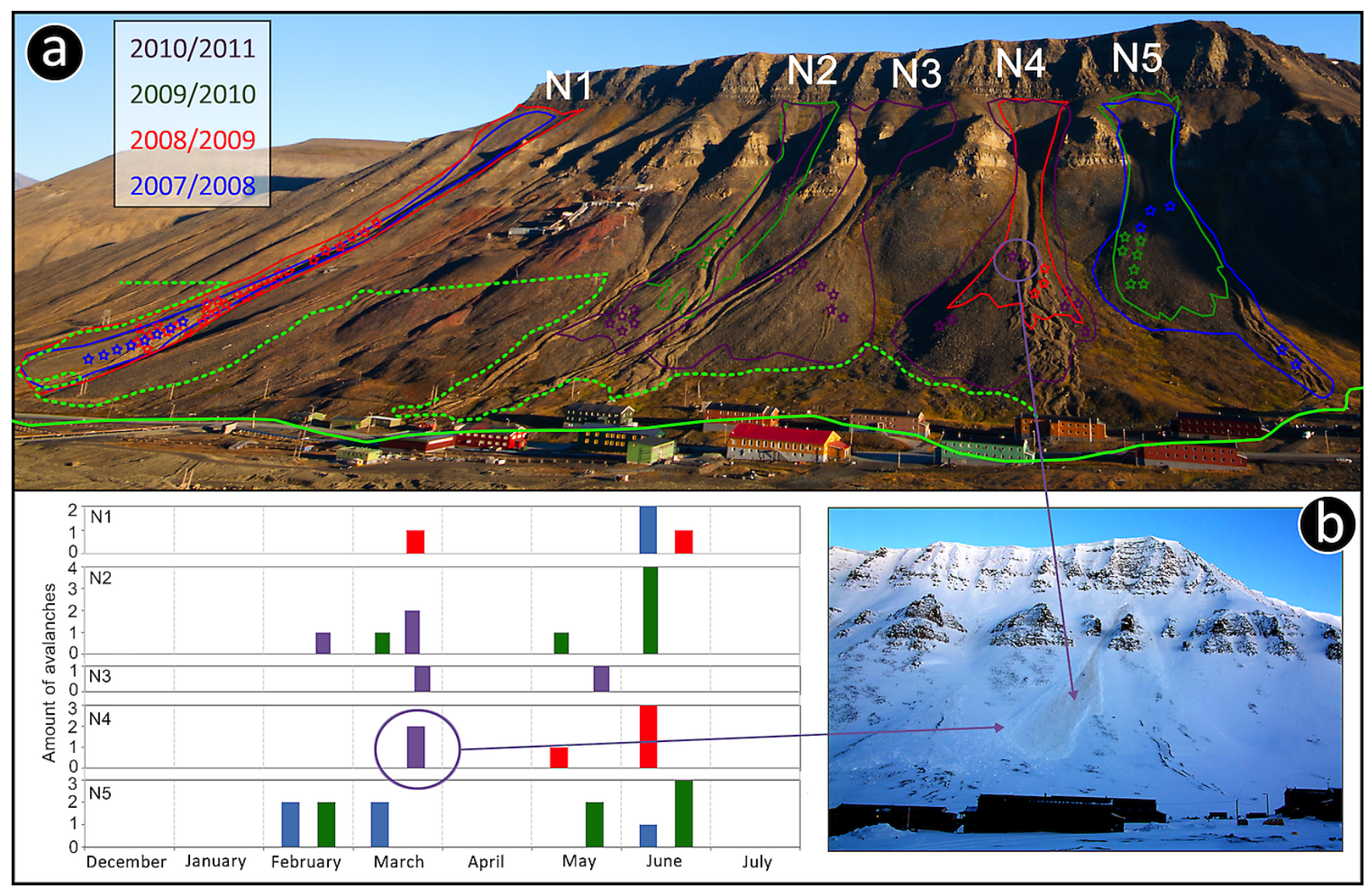

Fig. 5. (a) Outlines of the maximum annual extent of avalanche snow deposition in the Nybyen slope system. The stars indicate the location of directly measured avalanche deposited rock debris from sediment or snow traps. (b) Amount of annual avalanches that released in each catchment (Table 1a). The photograph shows an avalanche that released in March 2011 in catchment N4, and from which rock debris was sampled in June 2011. Note the high visible rock debris content in the avalanche that originated directly from the plateau edge and the free rock face, as the avalanche was not a full-depth release. Note also the swept free rock face, where the avalanche cleared rock debris of different origin.

not result in larger avalanche fan-surface accretion rates and rockwall retreat rates.

\section{Discussion}

\subsection{Differences in avalanche sedimentation between the Nybyen and Larsbreen slope systems}

Both the Nybyen and Larsbreen slope systems are developed in a similar geological setting with roughly similar slope aspect towards west and northwest. The Nybyen slope system has a larger vertical relief than Larsbreen, as well as a larger run $(600 \mathrm{~m}$ and $200-350 \mathrm{~m}$, respectively). The relationship between height and run is roughly similar for the two systems (ranging from 0.48 to 0.6 ), but the slope profiles are quite different, with much deeper incised gullies or couloirs at Nybyen, which cause intermediate depositional areas to exist in the upper part of the slope as well (Supplement Fig. 3 and Table 1). The Larsbreen slope system is topographically smoother, with a much larger source-to-depositional-area ratio, and no intermediate deposition landforms (Supplement Fig. 4 and Table 1).

Thus, the different slope system-specific rockwall retreat rates are a function of the complexity of the catchments. The intermediate storage (Krautblatter and Dikau, 2007) at the Nybyen slope is, in contrast to Larsbreen, well developed as several parts of the catchments have a thick sediment cover already in the first depositional area (Supplement Fig. 3a, Table 1). In the upper catchments, the vertical free rock face transitions immediately into the primary avalanche fans. When cornices melt down in situ instead of collapsing, embedded rock debris can be deposited on the plateau edge, the horizontal ledges of the free rock face or the upper fans, acting as another intermediate storage. Consequently, large cornice fall avalanches not only transport plucked rock debris from the plateau edge but also sweep rock debris deposited by melting cornices and rockfalls in previous years from the ledges of the free rock face and the 


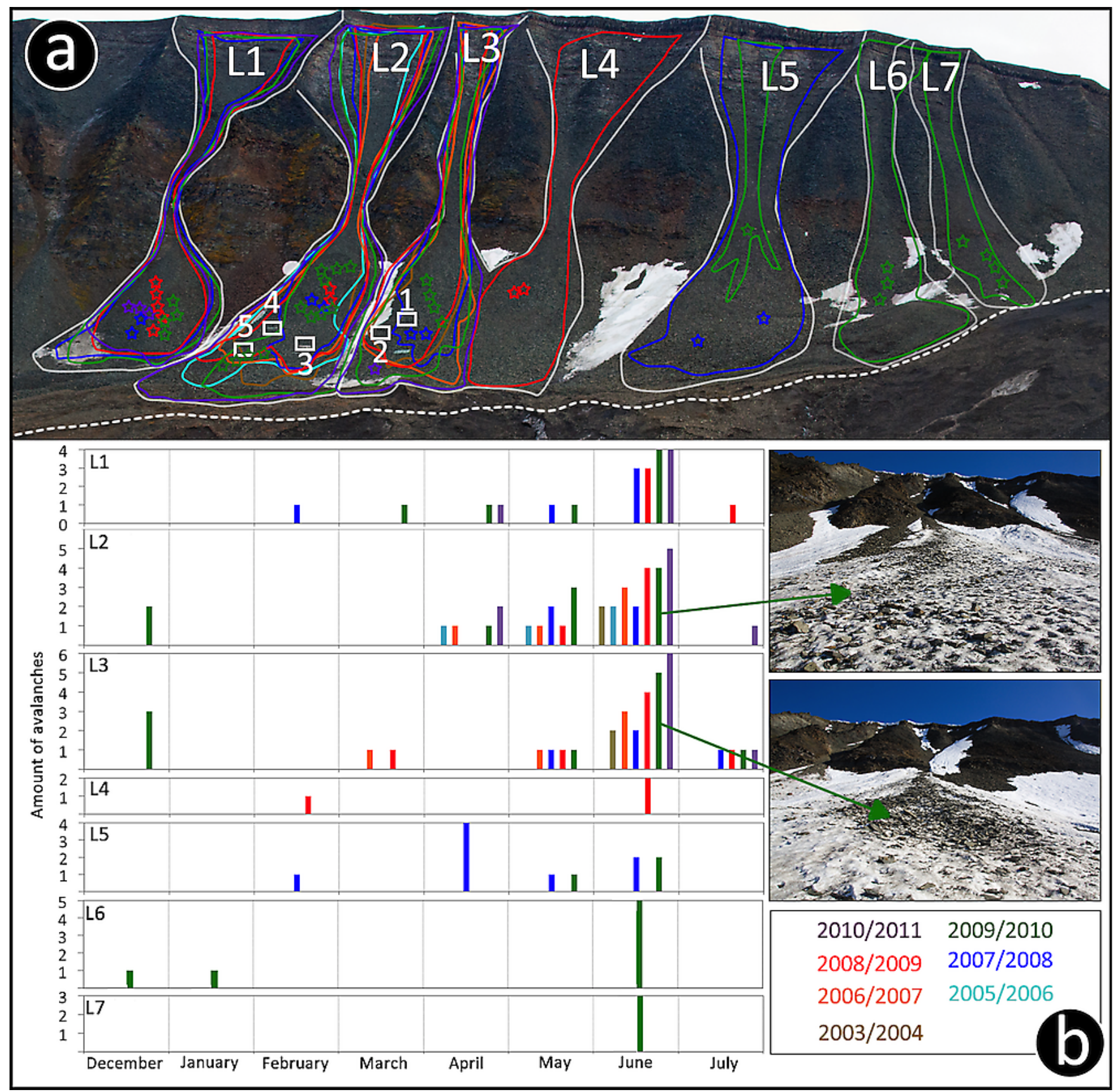

Fig. 6. (a) Outlines of the maximum annual extent of avalanche snow deposition in the Nybyen slope system. The stars indicate the location of directly measured avalanche deposited rock debris from sediment or snow traps. (b) Amount of annual avalanches that released in each catchment (Table 1). The two pictures exemplify two avalanche snow deposits in which snow inventories were carried out. The avalanches released in catchments L2 and L3 in 2009/2010. Note the highly visible rock debris content in both avalanches.

upper fans. Avalanche and rockfall deposits stored temporarily in the transport couloirs are typically only swept away by full-depth cornice fall avalanches at the end of the snow season, when just little snow is left on the slopes. Only in cornice fall avalanches can larger quantities of rockfall debris be transported down to the primary avalanche fans in one event (Supplement Fig. 3a-d).
The most striking topographical difference between both slope systems is the steeper transition from the plateau to the free rock face at Larsbreen, being almost entirely vertical above catchments L5-L7 (Supplement Fig. 3d). Due to this vertical backwall, which is about $15-20 \mathrm{~m}$ high, a downwards-deforming cornice very quickly becomes 
unstable, as it is relatively unsupported compared to a cornice accreting on a less steep backwall.

\subsection{The geomorphological role of cornice fall avalanche sedimentation}

Avalanche fan-surface accretion rates and rockwall retreat rates at both studied slope systems are comparably high, primarily due to erosion by cornices (Eckerstorfer et al., 2013), and frequent cornice fall avalanching (up to 8 months per year) (Vogel et al., 2012), transporting rock debris in an efficient way. Additionally, both slope systems consist of highly frost-weathering-susceptible sandstones and shales, with a rather moderate rock strength and high amount of fractures (Siewert et al., 2012). Evidence for avalanche sedimentation being the dominant geomorphological process can be found in the rock debris composition on the avalanche fans. Primarily sandstones are found from the Grumantbyen Formation, varying in clast size from boulders to stones, and shales from the Basilika Formation (only at Nybyen) accounting for all the fines, as these shales are broken down in the transport process. In addition, perched boulders and rocks (Supplement Fig. 3f), and newly deposited rock debris found far out on the basal concavity of the fans, indicate primarily avalanche sedimentation. At Nybyen, avalanche deposits reach almost to the outermost limit of slope deposition, and at Larsbreen even beyond, accumulating rock debris onto the rock glacier and ice-cored moraine ridges (Supplement Fig. 3a). At Larsbreen, avalanche snow deposits turned to ice are visible in the fans, sheltered by a layer of avalanchedeposited rock debris (Supplement Fig. 3e). The stratigraphy with rock debris and avalanche snow turned to ice is visible in a cave underneath the rock glacier (Humlum et al., 2007). Thus, cornice fall avalanches provide enough fresh rock debris and snow to the starting zone of the rock glacier below the avalanche fans, allowing for it to have grown to its relatively large size (Humlum et al., 2007).

Siewert et al. (2012) calculated Holocene rockwall retreat rates, based on ERT mapping of avalanche fan deposits along both sides of the Longyeardalen valley. Their calculations indicate comparable average Holocene rockwall retreat rates of $1.1 \mathrm{~mm} \mathrm{yr}^{-1}$ at the Nybyen slope system to the modern day $0.9 \mathrm{~mm} \mathrm{yr}^{-1}$ rate from this study (N5 in 2010/2011) and $0.5 \mathrm{~mm} \mathrm{yr}^{-1}$ Holocene rockwall retreat rates for the southeast-facing side of the valley. HartmannBrenner (1974) also calculated average Holocene rockwall retreat rates of $0.7 \mathrm{~mm} \mathrm{yr}^{-1}$ for the southeast-facing slopes in the Longyeardalen valley. From a large debris flow event in 1972, Larsson (1982) reported rockwall retreat rates of maximum $0.013 \mathrm{~mm} \mathrm{yr}^{-1}$, which indicates that debris flows are of much less importance for rockwall retreat than cornice fall avalanching in the Longyeardalen valley. It can thus be concluded that, due to comparable average Holocene and modern-day rockwall retreat rates at Nybyen, cornice fall avalanche activity could have been active with the same mag- nitude and frequency during large parts of the Holocene. This assumption is supported by the large size of the Larsbreen rock glacier, being actively supplied with rock debris and snow from avalanche sedimentation.

The presented avalanche fan-surface accretion rates and rock wall retreat rates show that, on the studied sedimentary rockslopes, avalanches are most likely the dominating geomorphological erosion, transport and depositional agent. Presumably, there is no other periglacial slope process that is as active and significant as the demonstrated cornice fall avalanches. The presented study thus adds to the understanding of rock weathering, rockslope erosion, and transport, as well as associated avalanche sedimentation. As glaciations determine landscape evolution on large temporal and spatial scales, periglacial processes act normally on a much smaller scales (Berthling and Etzelmüller, 2011). Rapp (1960) and Andre (1997) found a discrepancy between small presentday and significantly higher Holocene rockwall retreat rates in central and northwest Spitsbergen. However, this does not seem to be the case on the northwest-facing slopes of Longyeardalen, where slope development is mostly controlled by cornice fall avalanche sedimentation. In relative short time periods, large quantities of rock sediment are made available for future removal during glacial advances (Ballantyne, 2002). The exhaustion model of paraglacial activity does not necessarily only have one peak of maximum sediment availability shortly after deglaciation but can also have secondary peaks, due to a climate-induced change in wind direction or the sudden cut or occurrence of a water source. If climate changes, particularly if the dominant winter wind direction changes, avalanche sedimentation will likely adjust accordingly, leading to changes in the location of areas with quick avalanche sedimentation and thus possibilities for rock glacier and avalanche fans. Examples of this can found in the valley Todalen, close to the Longyeardalen valley. Here, several multi-genetic colluvial fans consisting of former avalanche deposits with old debris flow imprints are superimposed by avalanche and rockfall deposits because of a slight shift in wind direction (Rubensdotter et al., 2009).

\subsection{Possible errors and uncertainties}

Combined field-based monitoring and automatic time-lapse photography enabled a complete record of cornice fall avalanche activity. The maximum areas of avalanche snow deposition (Table 1b) were calculated by drawing a generalized outline in ArcGIS from photographs, keeping a possible overestimation of the avalanche deposits consistent.

The choice of location of the snow inventories was biased towards areas with large visible quantities of rock debris ablating out of the snow. However, in many catchments, a high number of snow inventories were performed each year, counterbalancing the preferential sampling. Moreover, the calculated mean rock debris sedimentation rates (Table 1e) derived from the snow inventories are largely within the range of 
the permanent sediment traps. Still, there exists a difference in timing of collection between permanent sediment traps and snow inventories. Potentially some rockfall in summer could have been included in the quantification of sediment in the permanent traps, as they were all sampled at the end of summer during snow minimum. We assume that about $10 \%$ of the rock wall retreat rates contain rockfall debris. In each catchment, at both slope systems, at least one cornice fall avalanche swept the free rock faces and the transport couloirs, thus removing almost all rock debris of different origin annually.

The rock debris sampling is based on individual sediment trap measurements (Table 1c), extrapolated onto the entire snow avalanche area (Table $1 \mathrm{~b}$ ), which is determined as the annual maximum extent that all avalanches reached in a catchment. A large number of sampling sites per catchment did not necessarily result in a larger amount of rock debris sampled. Therefore, the avalanche fan-surface accretion (Table $2 b$ ) and rock wall retreat rates (Table $2 \mathrm{c}$ ) are maximum rates.

\section{Conclusions}

A record of maximum seven years of avalanche sedimentation from two slope systems in the valley Longyeardalen, in central Svalbard, is presented. Avalanche monitoring was carried out by daily time-lapse photography and direct field observations, ensuring a complete record. Permanent sediment traps and snow inventories on the avalanche fans allowed for quantification of avalanche fan-surface accretion rates and rockwall retreat rates.

At both slope systems, rockwall retreat rates were found to be comparably high due to rock sediment plucking by cornices, and due to erosion and transport by frequent cornice fall avalanches throughout the entire winter. This results in the formation of quickly accreting avalanche fans with a bimodal clast size distribution, poor sorting and aggrading permafrost with a high ice content. A significant result is the formation of a rock glacier in the lower part of the Larsbreen slope system, suggesting that the ongoing cornice fall avalanche activity must have been comparable in magnitude and frequency during the Holocene. The present-day rockwall retreat rates, being in the range of the average Holocene rates, supports this assumption. Differential avalanche sedimentation rates between slope systems, with higher rates at Larsbreen, stem from its simpler system, with a shorter distance from the cornice source area to the depositional area, as well as a more favorable topography for cornice fall avalanche activity.

In conclusion, cornice fall avalanches are at present by far the most efficient geomorphological erosion and transport agent on northwest-facing slopes in the valley Longyeardalen. As cornice fall avalanches are the most dominant type of avalanche in the Longyearbyen area, they are likely to be the dominant mode of sediment transport of any leeward slope. Climate-induced changes in the dominant winter wind direction can then lead to significant changes in rockslope sedimentation from resulting avalanching.

\section{Supplementary material related to this article is available online at: http://www.the-cryosphere.net/7/ 1361/2013/tc-7-1361-2013-supplement.pdf.}

Acknowledgements. Thanks to Jonas Ellehauge, Knut Stalsberg, Jordan R. Mertes, Ulli Neumann, Jørgen Haagensli, Ole Humlum and the IPY Summer School 2009 students for assistance with rock debris sampling. Thanks to Wesley R. Farnsworth for fieldwork assistance during geomorphological mapping. We would like to acknowledge the very helpful comments by the editor Stephan Gruber, and by Oliver Sass and another anonymous referee. The paper significantly benefited in its clarity, structure and content.

Edited by: S. Gruber

\section{References}

Ackroyd, P.: Erosion by snow avalanche and implications for geomorphic stability, Torlesse Range, New Zealand, Arctic Alpine Res., 19, 65-70, 1987.

Åkerman, H. J.: Notes on talus morphology and processes in Spitsbergen, Geogr. Ann. A, 66, 267-284, 1984.

Åkerman, H. J.: Relations between slow slope processes and activelayer thickness 1972-2002, Kapp Linne, Svalbard, Norsk Geogr. Tidsskr., 59, 116-128, 2005.

André, M.-F.: Geomorphic impact of spring avalanches in Northwest Spitsbergen $\left(79^{\circ} \mathrm{N}\right)$, Permafrost Periglac., 1, 97-110, doi:10.1002/ppp.3430010203, 1990.

André, M.-F.: Holocene climate fluctuations and geomorphic impact of extreme events in Svalbard, Geogr. Ann. A, 77, 241-250, 1995.

André, M.-F.: Geological control of slope processes in northwest Spitsbergen, Norsk Geogr. Tidsskr., 50, 37-40, 1996.

André, M.-F.: Holocene rockwall retreat in Svalbard: A triple-rate evolution, Earth Surf. Proc. Land., 22, 423-440, 1997.

André, M.-F.: Do periglacial landscapes evolve under periglacial conditions?, Geomorphology, 52, 149-164, doi:10.1016/s0169$555 \times(02) 00255-6,2003$.

Bell, I., Gardner, J., and DeScally, F.: An estimate of snow avalanche debris transport, Kaghan Valley, Himalaya, Pakistan, Arct. Antarct. Alp. Res., 22, 317-321, 1990.

Blikra, L. H. and Selvik, S. F.: Climatic signals recorded in snow avalanche-dominated colluvium in western Norway: depositional facies successions and pollen records, Holocene, 8, 631$658,1998$.

Caine, T. N.: A uniform measure of subaerial erosion, Geol. Soc. Am. Bull., 87, 137-140, 1976.

Christiansen, H. H.: Snow-cover depth, distribution and duration data from northeast Greenland obtained by continu- 
ous automatic digital camera, Ann. Glaciol., 32, 102-108, doi:10.3189/172756401781819355, 2001.

Christiansen, H. H., Blikra, L. H., and Mortensen, L. E.: Holocene slope processes and landforms in the northern Faroe Islands, Earth Environ. Sci. Trans. R. Soc. Edinb., 98, 1-13, doi:10.1017/S1755691007000047, 2007.

Decaulne, A. and Saemundsson, T.: Geomorphic evidence for present-day snow-avalanche and debris-flow impact in the Icelandic Westfjords, Geomorphology, 80, 80-93, doi:10.1016/j.geomorph.2005.09.007, 2006.

Eckerstorfer, M. and Christiansen, H. H.: Topographical and meteorological control on snow avalanching in the Longyearbyen area, central Svalbard 2006-2009, Geomorphology, 134, 186196, doi:10.1016/j.geomorph.2011.07.001, 2011.

Eckerstorfer, M., Christiansen, H. H., Vogel, S., and Rubensdotter, L.: Snow cornice dynamics as a control on plateau edge erosion in central Svalbard Earth Surf. Proc. Land., 38, 466-476, doi:10.1002/esp.3292, 2013.

Etzelmueller, B., Ødegård, R. S., Vatne, G., Mysterud, R. S., Tonning, T., and Sollid, J. L.: Glacier characteristics and sediment transfer system of Longyearbreen and Larsbreen, western Spitsbergen, Norsk Geogr. Tidsskr., 54, 157-168, doi:10.1080/002919500448530, 2000.

French, M. H.: The periglacial environment, John Wiley \& Sons, 2007.

Hartmann-Brenner, D.-C.: Ein Beitrag zum Problem der Schutthaldenentwicklung an Beispielen des Schweizerichen Nationalparks und Spitzbergens, Doctoral Thesis, University of Zuerich, 1974.

Heckmann, T., Wichmann, V., and Becht, M.: Quantifying sediment transport by avalanches in the Bavarian Alps - first results, Z. Geomorphol., N.F., 127, 137-152, 2002.

Heckmann, T., Wichmann, V., and Becht, M.: Sediment transport by avalanches in the Bavarian Alps revisited - a perspective on modelling, Z. Geomorphol., N.F., 138, 11-25, 2005.

Hjelle, A.: The Geology of Svalbard, Polarhåndbok, Norsk Polarinstitutt, Oslo, 1993.

Humlum, O., Christiansen, H. H., and Juliussen, H.: Avalanchederived rock glaciers in Svalbard, Permafrost Periglac., 18, 7588, doi:10.1002/ppp.580, 2007.

Jahn, A.: Some features of mass movement on Spitsbergen slopes, Geogr. Ann. A, 49, 213-224, 1967.

Jahn, A.: Contemporaneous geomorphological processes in Longyeardalen, Vestspitsbergen (Svalbard), Biuletyn Peryglacjalny, 26, 252-268, 1976.
Jahn, A.: Periglacial talus slopes. Geomorphological studies on Spitsbergen and in Northern Scandinavia, Polar Geogr. Geol., 8, 177-193, 10.1080/10889378409377224, 1984.

Krautblatter, M. and Dikau, R.: Towards a uniform concept for the comparison and extrapolation of rockwall retreat and rockfall supply, Geogr. Ann. A, 89, 21-40, doi:10.1111/j.14680459.2007.00305.x, 2007.

Larsson, S.: Geomorphological effects on the slopes of Longyear valley, Spitsbergen, after a heavy rainstorm in July 1972, Geogr. Ann. A, 64, 105-125, 1982.

Luckman, B. H.: The geomorphic activity of snow avalanches, Geogr. Ann. A, 59, 31-48, 1977.

Luckman, B. H.: Geomorphic work of snow avalanches in the Canadian Rocky Mountains, Arctic and Alpine Res., 10, 261-276, 1978a.

Luckman, B. H.: The measurement of debris movement on alpine talus slopes, Z. Geomorphol., N.F., Suppl. Bd., 29, 117-129, 1978b.

Luckman, B. H.: Debris accumulation patterns on talus slopes in Surprise Valley, Alberta, Geogr. Phys. Quatern., 42, 247-278, 1988.

Met.no: eKlima: Free access to weather- and climate data from Norwegian Meteorological Institute form historical data to real time observations, available at: http://www.eklima.no, 2013.

Rapp, A.: Talus slopes and mountain walls at Tempelfjorden, Spitsbergen, Norsk Polarinstitut Skrifter, 119, 1960a.

Rapp, A.: Recent developments of mountain slopes in Kärkevagge and surroundings, northern Scandinavia, Geogr. Ann. A, XLII, 71-200, 1960b.

Sass, O., Hoinkis, R., and Wetzel, K.-F.: A six-year record of debris transport by avalanches on a wildfire slope (Arnspitze, Tyrol), Z. Geomorphol., N.F., 54, 181-193, 2010.

Schrott, L., Niederheide, A., Hankammer, M., Hufschmidt, G., and Dikau, R.: Sediment storage in a mountain catchment: geormorphic coupling and temporal variability (Reintal, Bavarian Alps, Germany), Z. Geomorphol., N.F., Suppl.-Bd., 127, 175196, 2002.

Siewert, M. B., Krautblatter, M., Christiansen, H. H., and Eckerstorfer, M.: Arctic rockwall retreat rates estimated using laboratory-calibrated ERT measurements of talus cones in Longyeardalen, Svalbard, Earth Surf. Proc. Land., 37, 1542 1555, doi:10.1002/esp.3297, 2012.

Vogel, S., Eckerstorfer, M., and Christiansen, H. H.: Cornice dynamics and meteorological control at Gruvefjellet, Central Svalbard, The Cryosphere, 6, 157-171, doi:10.5194/tc-6-157-2012, 2012. 